\title{
ALOKASI REMITANSI PENDAPATAN KELUARGA MIGRAN DI KECAMATAN LANGOWAN UTARA
}

\author{
Junita Rantung \\ Celcius Talumingan \\ Ellen G. Tangkere
}

\begin{abstract}
This study aims to determine the allocation of remittance of migrant family income in North Langowan Subdistrict. This study uses descriptive analysis, by conducting surveys or field observations to determine the utilization of remittances by the families of migrant workers. The research was conducted in February to May 2018 in North Langowan Subdistrict, in Walantakan Village, Toraget Village, Karumenga Village, Taraitak Village and Taraitak Village 1. The method used in this research is survey method by taking primary data and secondary data. Primary data collection is intended to know the clear picture of the utilization of Indonesian labor remittances for consumption, investment and savings or for agriculture or not. The primary data collection technique was carried out by direct interviews and the questionnaire distributed to the families of migrant workers regarding the pattern of money management of remittances. Secondary data was obtained from North Langowan Subdistrict office. The results of this study indicate that most migrants allocate remittances to renovate houses or buy land / houses, from which $40 \%$ to $50 \%$ of the remuneration is used for the allocation. Some of the migrants make use of remittances to buy houses for investment and partly to finance children's education. Some of the migrants use remittances to buy rice fields as another form of investment, and only a small percentage of migrants make use of remittances to buy cars as a tertiary family need. Remittance remained for savings. Migration in addition to affecting the increase in income and welfare of migrant families also affects the development of land prices in North Langowan Subdistrict.*er*
\end{abstract}

Keywords: remittance, migrant family income, North Langowan Subdistrict.

\begin{abstract}
ABSTRAK
Penelitian ini bertujuan untuk mengetahui alokasi remitansi pendapatan keluarga migran di Kecamatan Langowan Utara. Penelitian ini menggunakan analisis secara deskriptif, dengan melakukan survei atau pengamatan di lapangan untuk mengetahui pemanfaatan remitansi yang dilakukan keluarga buruh migran. Penelitian dilaksanakan pada Bulan Februari sampai Mei 2018 di Kecamatan Langowan Utara tepatnya di Desa Walantakan, Desa Toraget, Desa Karumenga, Desa Taraitak dan Desa Taraitak 1. Metode yang digunakan dalam penelitian ini adalah metode survey dengan cara mengambil data primer dan sata sekunder. Pengumpulan data primer yang di maksud yaitu untuk mengetahui gambaran secara jelas pemanfaatan remitansi tenaga kerja Indonesia untuk konsumsi, investasi dan tabungan atau untuk pertanian atau tidak. Teknik pengumpulan data primer dilaksanakan dengan wawancara langsung serta penyebaran kuesioner terhadap keluarga buruh migran mengenai pola pengelolaan uang kiriman (remitansi). Data sekunder diperoleh dari kantor Kecamatan Langowan Utara. Hasil penelitian ini menunjukkan bahwa kebanyakan migran mengalokasikan remitansi untuk merenovasi rumah atau membeli tanah/rumah, dimana dari remintansi yang diterima 40\% sampai 50\% digunakan untuk alokasi tersebut. Sebagian dari migran memanfaatkan remitansi untuk membeli rumah sebagai investasi dan sebagian lagi untuk membiayai pendidikan anak. Sebagian lagi dari migran memanfaatkan remitansi untuk membeli sawah sebagai bentuk investasi lain, dan hanya sebagian kecil dari migran memanfaatkan remitansi untuk membeli mobil sebagai kebutuhan tersier keluarga. Sisa remitansi digunakan untuk tabungan. Migrasi selain dapat mempengaruhi peningkatan pendapatan dan kesejahteraan keluarga migran juga mempengaruhi perkembangan harga tanah di Kecamatan Langowan Utara. *er*
\end{abstract}

Kata kunci: remitasi, pendapatan keluarga migran, Kecamatan Langowan Utara. 


\section{PENDAHULUAN}

\section{Latar Belakang}

Penerimaan remitansi merupakan sumber pendapatan yang penting bagi beberapa negara berkembang. Remitansi yang dihasilkan oleh para migran berpotensi untuk meningkatkan pendapatan negara dan dapat menurunkan tingkat kemiskinan. Selain itu, remitansi juga dapat meningkatkan pembangunan sektor keuangan, sehingga dapat merangsang pertumbuhan ekonomi. Dampak positif lainnya dari remitansi yaitu pada tingkat kredit suatu negara, menyediakan sumber dan menstabilkan mata uang asing, membantu mengatasi neraca pembayaran dari krisis. Akan tetapi, remitansi juga dapat memberikan dampak negatif dengan menurunkan upaya kerja dan pada jangka panjang dapat mengurangi pertumbuhan ekonomi (Ratha. 2011). Selain itu, remitansi dapat memberikan dampak negatif terhadap perekonomian nasional apabila remitansi lebih banyak digunakan untuk belanja barang impor (Belmimoun et al. 2014). Remitansi merupakan sumber yang cukup penting yang digunakan untuk biaya pendidikan anakanaknya maupun keluarga dekatnya dan juga untuk keperluan akumulasi invastasi dan modal keluarga.

Berdasarkan observasi yang dilakukan di Kecamatan Langowan Utara yaitu di Desa Karumenga, Walantakan, Toraget. Telah banyak ditemui keberhasilan dari masyarakat migran dalam meningkatkan kesejahteraannya jauh lebih baik dari sebelum menjadi migran. Kesejahteraan dapat di ukur atau dilihat secara fisik yaitu dengan adanya peningkatan pendapatan untuk memenuhi kebutuhannya.

Hubungan migran dengan daerah asal diwujudkan dalam bentuk pengiriman materi balik atau disebut juga dengan Remitansi. Remitansi telah menjadi perhatian dalam literatur keuangan internasional karena volume dan potensi remitansi untuk mengurangi kemiskinan. Kualitas dan kuantitas pemanfaatan remitansi sangat bervariasi pada setiap pekerja migran, tergantung pada jumlah remitansi yang bisa diperoleh, dikumpulkan, dikirim, serta dibawa pulang oleh mereka. Penggunaan utama remitansi adalah untuk membayar hutang, memenuhi kebutuhan hidup sehari-hari, membangun rumah/memperbaiki rumah dan membeli perabot rumah tangga. Apabila ada uang lebih setelah dibelanjakan untuk keperluan utama tersebut, maka akan diinvestasikan dalam bentuk emas, sepeda motor, tanah, sawah, ternak dan membayar biaya pendidikan anak. Sangat sedikit yang berhasil menginvestasikan remitansi dalam suatu usaha dan berhasil mengembangkannya secara berkelanjutan. Jika remitansi menjadi sumber penghasilan utama atau satu-satunya bagi keluarga pekerja migran, remitansi cenderung habis untuk memenuhi kebutuhan hidup sehari-hari. Jika pekerja migran berasal dari latar belakang ekonomi yang relatif cukup mapan, remitansi dapat dikumpulkan untuk meningkatkan aset keluarga.

Sutanto Edi (2004), mengemukakan bahwa dengan munculnya kesepakatan dan imigrasi antar Negara akan memacu terjadinya peningkatan pendapatan sebagai implikasi langsung dari remitan dan besarnya jumlah imigrasi. Disamping itu mobilitas penduduk berpengaruh terhadap modernisasi pedesaan baik dalam aspek-aspek ekonomis maupun dalam aspek-aspek sosiologis. Aspek-aspek ekonomis meliputi perubahan ketenagakerjaan, remitan, distribusi dan tingkat pendapatan, produktivitas desa. Aliran remitansi ini dimanfaatkan untuk berbagai keperluan keluarga, seperti memperbaiki kondisi kehidupan rumah tangga serta membangun atau memperbaiki rumah. Sebagian keluarga pekerja migran menggunakan uang kiriman untuk mengembangkan usaha ekonomi produktif skala kecil, membiayai pendidikan anak, dan membeli tanah.

Perpindahan faktor produksi tenaga kerja ke luar negeri salah satunya disebabkan oleh perbedaan pendapatan yang diterima dengan bekerja di daerah asal dibandingkan bekerja di luar negeri. Tenaga Kerja Indonesia (TKI) memilih bekerja di luar negeri untuk meningkatkan kesejahteraan keluarganya melalui pekerjaan yang lebih baik dan pendapatan yang lebih tinggi dinegara tujuan.

\section{Rumusan Masalah}

Berdasarkan latar belakang yang telah dikemukakan, hal yang menjadi rumusan masalah dalam penelitian ini adalah bagaimana alokasi remitansi pendapatan keluarga migran di Kecamatan Langowan Utara. 


\section{Tujuan Penelitian}

Tujuan dari penelitian ini untuk mengetahui apa saja alokasi remitansi pendapatan keluarga migran di Kecamatan Langowan Utara.

\section{Manfaat Penelitian}

Hasil penelitian ini diharapkan dapat memberikan manfaat, mendapatkan pengetahuan tentang remitansi terhadap pendapatan keluarga migran. Bagi penulis adalah untuk memperoleh pengalaman, informasi, dan wawasan baru.

\section{METODE PENELITIAN}

\section{Waktu dan Tempat Penelitian}

Penelitian berlangsung selama 3 bulan, dari bulan Februari sampai bulan Mei dari persiapan sampai penyusunan laporan hasil penelitian. Penelitian dilaksanakan di Kecamatan Langowan Utara.

\section{Metode Pengambilan Data}

Metode yang digunakan dalam penelitian ini adalah metode survey dengan cara mengambil data primer dan sata sekunder. Pengumpulan data primer yang di maksud yaitu untuk mengetahui gambaran secara jelas pemanfaatan remitan TKI untuk konsumsi, investasi dan menabung atau untuk pertanian atau tidak. Teknik pengumpulan data primer dilaksanakan dengan wawancara langsung serta penyebaran kuesioner terhadap keluarga buruh migran mengenai pola pengelolaan uang kiriman (remitansi). Data sekunder diperoleh dari kantor Kecamatan Langowan Utara.

\section{Metode Pengambilan Sampel}

Pengambilan sampel dalam penelitian ini dilakukan secara purpossive sampling, secara senagaja dengan batasan-batasan yang menjadi sampel dalam penelitian ini adalah keluarga didesa yang telah menerima remitansi. Jumlah sampel dalam penelitian ini 34 sampel. Dari 5 desa yaitu Desa Walantakan 6 sampel, Karumenga 12 sampel,
Toraget 6 sampel, Taraitak 5 sampel, Taraitak Satu 5 sampel.

\section{Konsep Pengukuran Variabel}

Variabel-variabel yang diukur dalam penelitian ini adalah:

1) Remitansi yang diterima yaitu: keluarga yang telah menerima uang dari seseorang yang telah bekerja di luar negeri (Rp/bulan-Rp/tahun).

2) Pendapatan sebelum melakukan migrasi.

3) Pendapatan: penerimaaan yang diterima oleh TKI selama bekerja di luar negeri (Rp/bulan).

4) Jumlah konsumsi/tanggungan keluarga migran: sejumlah pengeluaran yang digunakan untuk mengkonsumsi kebutuhan sehari-hari oleh keluarga TKI di daerah asal (Rp/bulan).

5) Jenis kelamin : jenis kelamin responden yang bekerja di luar negeri.

6) Pendidikan: Pendidikan terakhir dari TKI.

7) Status pekerjaan.

8) Jumlah anggota keluarga: jumlah anggota keluarga TKI di daerah asal yang dalam kebutuhan hidupnya masuk dalam tanggungan TKI

\section{Analisis Data}

Data yang dikumpulkan dalam penelitian ini di analisis secara deskriptif, dengan melakukan survei atau pengamatan di lapangan untuk mengetahui pemanfaatan remitansi yang dilakukan keluarga buruh migran. apakah berperan terhadap pendapatan petani. Karena, sebagian besar penerima Remitansi adalah petani.

\section{HASIL DAN PEMBAHASAN}

Dalam hasil dan pembahasan penelitian ini kata migran yang dimaksud adalah seorang yang tinggal di Langowan Utara tepatnya di Desa Walantakan, Karumenga, Toraget, Taraitak, Taraitak Satu yang sedang bekerja diluar negri yaitu Negara Amerika, Jepang, Hongkong, Singapura, Spanyol Dan Korea. 


\section{Deskripsi Lokasi Penelitian Wilayah Kecamatan Langowan Utara}

\section{Keadaan Geografi}

Secara umum Kondisi topografi dan monografi tanah Sulawesi utara tidak terlepas dari bagian dari gugusan bukit atau gunung dan sungai yang berada didaerah ini dan merupakan daerah rendah dikawasan sektor pantai. Keadaan topografis Wilayah Kecamatan Langowan Utara Kabupaten Minahasa adalah datar. Letak Geografis Kecamatan Langowan Utara yaitu pada 1'08 1'09 LU dan 124'68' - 124' 86" BT.

Kecamatan Langowan Utara Kabupaten Minahasa pada umumnya beriklim sejuk. Temperatur udara antara $22-32{ }^{\circ} \mathrm{C}$.

Adapun batas-batas Wilayah Kecamatan Langowan Utara adalah sebagai berikut:

a. Sebelah Utara berbatasan dengan Kecamatan Tompaso.

b. Sebelah Selatan berbatasan dengan Kecamatan Langowan Timur.

c. Sebelah Timur berbatasan dengan Kecamatan Langowan Timur dan Kecamatan Kakas.

d. Sebelah Barat berbatasan dengan Kecamatan Langowan Barat

\section{Luas Wilayah}

Pembagian luas wilayah menurut desa dapat dilihat pada Table 1.

Tabel 1. Luas Wilayah Kecamatan Langowan Utara Berdasarkan Dari Banyak Desa

\begin{tabular}{llcc}
\hline No & \multicolumn{1}{c}{ Desa } & $\begin{array}{c}\text { Luas Wilayah } \\
\left(\mathrm{km}^{2}\right)\end{array}$ & $\%$ \\
\hline 1. & Walantakan & 0,36 & 6,9 \\
2. & Taraitak & 1,10 & 21,11 \\
3. & Taraitak Satu & 1,04 & 19,96 \\
4. & Toraget & 0,52 & 9,9 \\
5. & Karumenga & 0,8 & 15,35 \\
6. & Tempang & 0,45 & 8,6 \\
7. & Tempang Dua & 0,43 & 8,2 \\
8. & Tempang Tiga & 0,47 & 9,02 \\
\hline & Jumlah & 5,21 & 100 \\
\hline
\end{tabular}

Sumber: Data BPS Kecamatan Langowan Utara

\section{Kependudukan}

Jumlah penduduk wilayah kecamatan Langowan Utara sampai dengan bulan januari 2018, dapat dilihat pada Tabel 2 sebagai berikut:

\begin{tabular}{|c|c|c|c|c|c|c|}
\hline \multirow[t]{2}{*}{ No } & \multirow[t]{2}{*}{ Desa } & \multicolumn{3}{|c|}{ Jumlah Penduduk } & \multirow{2}{*}{$\begin{array}{l}\text { Jumlah Kepala } \\
\text { Keluarga (KK) }\end{array}$} & \multirow{2}{*}{$\begin{array}{c}\text { Jumlah } \\
\text { Jaga }\end{array}$} \\
\hline & & $\mathrm{L}$ & $\mathrm{P}$ & Jumlah & & \\
\hline 1. & Walantakan & 738 & 776 & 1.514 & 453 & 6 \\
\hline 2. & Taraitak & 378 & 417 & 795 & 281 & 4 \\
\hline 3. & Taraitak Satu & 432 & 456 & 879 & 285 & 4 \\
\hline 4. & Toraget & 728 & 669 & 1.397 & 478 & 6 \\
\hline 5. & Karumenga & 682 & 626 & 1.308 & 408 & 4 \\
\hline 6. & Tempang & 452 & 293 & 745 & 210 & 3 \\
\hline 7. & Tempang Dua & 384 & 338 & 722 & 224 & 3 \\
\hline \multirow[t]{2}{*}{8.} & Tempang Tiga & 537 & 471 & 1008 & 324 & 4 \\
\hline & Jumlah & 4.322 & 4.046 & 8.368 & 2.663 & 34 \\
\hline
\end{tabular}

Dari Tabel 2, dapat dilihat bahwa jumlah wilayah Kecamatan Langowan Utara pada bulan januari 2018 adalah 8.368 jiwa dengan 2.663 kepala keluarga. Dari data tersebut terlihat bahwa desa Walantakan memiliki penduduk yang lebih banyak dari desa-desa lain. Sedangkan desa Tempang Dua memiliki penduduk yang lebuh sedikit dibandingkan dengan desa lain.

\section{Deskripsi Daerah yang Diteliti}

Desa Walantakan Kecamatan Langowan Utara beriklim tropis dan terletak sekitar 600700 meter dari permukaan laut. Luas wilayah Desa Walantakan Kecamatan Langowan Utara kurang lebih $0,6 \mathrm{~km}^{2}$. Jumlah penduduk Desa Walantakan mencapai 1.514 jiwa dengan Jumlah kepala keluarga 453 yang menyebar di 6 jaga dan jumlah migran kurang lebih 6 orang.

Desa Karumenga Kecamatan Langowan Utara beriklim tropis dan terletak sekitar 600700 meter dari permukaan laut. Luas wilayah Desa Karumenga Kecamatan Langowan Utara kurang lebih $0,8 \mathrm{~km}^{2}$. Jumlah penduduk Desa Karumenga mencapai 1.308 jiwa dengan Jumlah kepala keluarga 408 yang menyebar di 4 jaga dan jumlah migran kurang lebih 12 orang.

Desa Toraget Kecamatan Langowan Utara beriklim tropis dan terletak sekitar 600700 meter dari permukaan laut. Luas wilayah Desa Toraget Kecamatan Langowan Utara kurang lebih $0,52 \mathrm{~km}^{2}$. Jumlah penduduk Desa Toraget mencapai 1.397 jiwa dengan Jumlah 
kepala keluarga 478 yang menyebar di 6 jaga dan jumlah migran kurang lebih 6 orang.

Desa Taraitak Kecamatan Langowan Utara beriklim tropis dan terletak sekitar 650-700 meter dari permukaan laut. Luas wilayah Desa Taraitak Kecamatan Langowan Utara kurang lebih 1,10 $\mathrm{km}^{2}$. Jumlah penduduk Desa Taraitak mencapai 795 jiwa dengan Jumlah kepala keluarga 281 yang menyebar di 4 jaga dan jumlah migran kurang lebih 5 orang.

Desa Taraitak Satu Kecamatan Langowan Utara beriklim tropis dan terletak sekitar 650-700 meter dari permukaan laut. Luas wilayah Desa Taraitak Satu Kecamatan Langowan Utara kurang lebih $1,04 \mathrm{~km}^{2}$. Jumlah penduduk Desa Taraitak Satu mencapai 879 jiwa dengan Jumlah kepala keluarga 285 yang menyebar di 4 jaga dan jumlah migran kurang lebih 5 orang.

\section{Karakteristik Responden/Migran Umur}

Umur akan mempengaruhi produktivitas dalam bekerja dan peranan dalam proses pengambilan keputusan di berbagai alternatif pekerjaan yang dilakukan.

Umur juga dapat mempengaruhi kemampuan seseorang untuk bekerja secara fisik serta menentukan cara berpikir. Menurut hasil penelitian di Desa Walantakan, Karumenga, Toraget, Taraitak, Taraitak Satu umur Migran dapat dilihat pada Tabel 3.

\section{Tabel 3. Golongan Umur Migran}

\begin{tabular}{ccc}
\hline \multirow{2}{*}{$\begin{array}{c}\text { Gologan Umur } \\
\text { (Tahun) }\end{array}$} & \multicolumn{2}{c}{ Total } \\
\cline { 2 - 3 } & Jumlah & $\%$ \\
\hline $20-30$ & 6 & 17,6 \\
$31-40$ & 17 & 50 \\
$>40$ & 11 & 32,3 \\
\hline Jumlah & 34 & 100 \\
\hline
\end{tabular}

Sumber: Data Primer

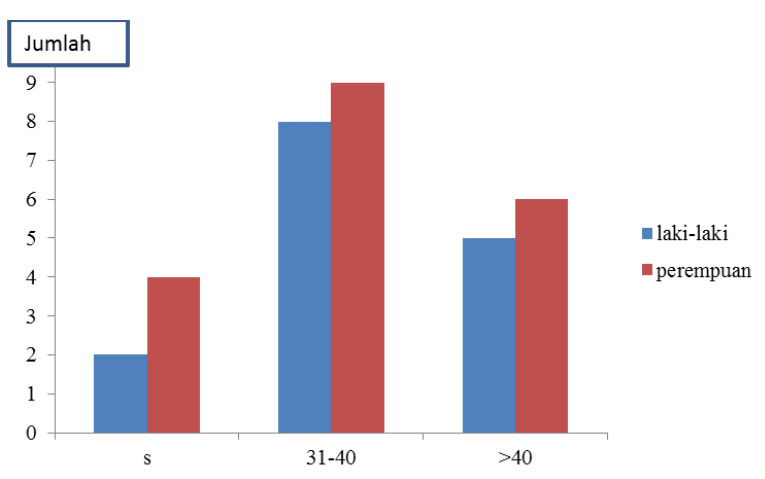

Gambar 1. Golongan Umur Migran Menurut Jenis Kelamin
Tabel 3 dan Gambar 1 menunjukkan bahwa sebagian besar dari para migran berusia 31-40 tahun berjumlah 17 orang dengan persentase $50 \%$ dari total migran keseluruhan dengan jumlah lakilaki 8 orang dan perempuan sebanyak 9 orang, selanjutnya jumlah responden berumur lebih dari 40 tahun sebanyak 11 orang dengan persentase $32,3 \%$ dari migran keseluruhan dengan jumlah laki-laki 5 orang dan perempuan 6 orang, dan migran dimana reponden berumur 20-30 tahun hanya sebanyak 6 orang dengan persentase sebesar $17,6 \%$ dari total migran keseluruhan dengan jumlah laki-laki 2 orang dan perempuan sebanyak 4 orang.

Umur ternyata bukan menjadi halangan bagi seseorang untuk melakukan migrasi. Semua tergantung pada keinginan, semangat dan tujuan migrasi untuk melakukan migrasi.

\section{Pendidikan}

Pendidikan merupakan salah satu faktor terpenting dalam meningkatkan kualitas dan produktivitas sumber daya manusia (SDM) sehingga pendidikan sering dijadikan tolak ukur terhadap keberhasilan seseorang. Namun tidak sama halnya dengan kenyataan yang ditemui oleh para migran, karena dengan pendidikan yang berbeda migran dapat melakukan migrasi. Berdasarkan hasil penelitian, tingkat pendidikan responden sangat bervariasi. Hal tersebut dapat dilihat pada Tabel 4 dan Gambar 2.

\begin{tabular}{ccc}
\multicolumn{2}{c}{ Tabel 4. Jumlah Migran Berdasarkan Tingkat Pendidikan } \\
\hline Tingkat Pendidikan & Jumlah & $\%$ \\
\hline SMP & 2 & 5,9 \\
SMA & 20 & 58,9 \\
SMK & 9 & 26,5 \\
D3 & 1 & 2,9 \\
S1 & 2 & 5,9 \\
\hline Jumlah & 34 & 100
\end{tabular}

Sumber: Data Primer

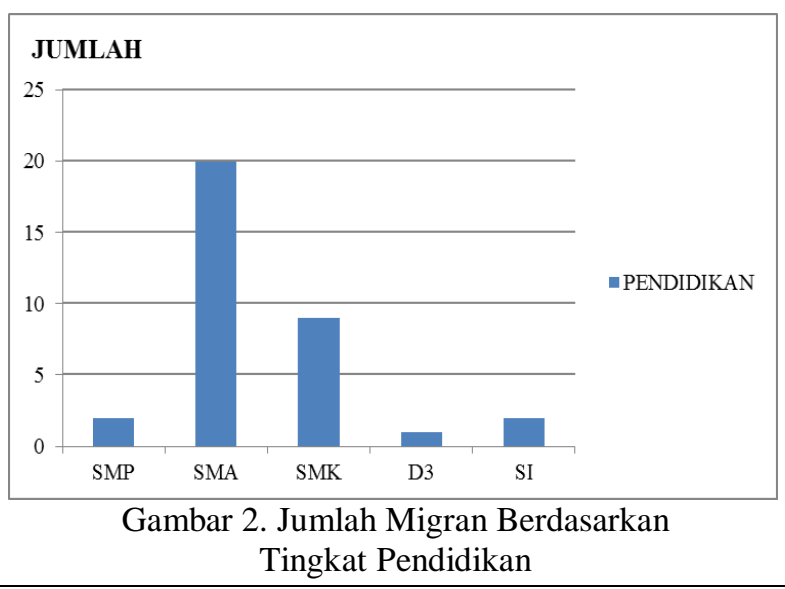


Data pada Tabel 4 dan Gambar 2, menunjukkan bahwa pada umumnya tingkat pendidikan migran yaitu SMA dengan sebanyak 21 orang atau 61,8\%, SMK berjumlah 9 orang dengan persentase $26,5 \%$, SMP berjumlah 2 orang dengan persentase $5,9 \%$, selanjutnya D3 berjumlah 1 orang dengan persentase $2,9 \%$, dan $\mathrm{S} 1$ berjumlah !orang dengan Persentase 2,9\%. Pendidikan tidak menjadi patokan seorang migran dapat melebihi migran yang lain dalam hal kesejahteraan, tetapi keterampilan, keahlian, dan kemampuan atau kinerja migranlah yang dapat menjadi penunjang dan merupakan suatu modal untuk mengembangkan potensi dirinya dalam bekerja.

\section{Migran Dilihat Dari Status Perkawinan}

Pada umumnya para migran mempunyai status belum menikah/single. Karena sebagian besar umur migran masih muda sewaktu pergi keluar daerah, yaitu pada interval umur 20-30 tahun. Apalagi migran lebih memprioritaskan untuk mencari uang sebanyak-banyaknya kemudian pulang dan menikah. Adapun status migran dapat dilihat pada Tabel 5.

Tabel 5. Status Migran Berdasarkan Golongan Umur

\begin{tabular}{|c|c|c|c|c|c|}
\hline \multirow[t]{2}{*}{ Status } & \multicolumn{3}{|c|}{ Umur } & \multirow[t]{2}{*}{ Jumlah } & \multirow[t]{2}{*}{$\%$} \\
\hline & $\begin{array}{l}20- \\
30\end{array}$ & $31-40$ & $>40$ & & \\
\hline Menikah & 4 & 13 & 11 & 28 & 82,4 \\
\hline $\begin{array}{l}\text { Belum } \\
\text { Menikah }\end{array}$ & 2 & 4 & - & 6 & 17,7 \\
\hline Jumlah & 6 & 17 & 11 & 34 & 100 \\
\hline
\end{tabular}

Tabel 5, menunjukkan bahwa status migran yang menikah mendominasi yaitu sebesar 28 orang atau $82,4 \%$. Umumnya yang belum menikah yaitu sebanyak 6 orang atau $17,7 \%$ dari total keseluruhan.

\section{Tahun Melakukan Migrasi}

Sekitar tahun 1998 para migran berbondong-bondong atau dengan kata lain ikut-ikutan menjadi migran dikarenakan biaya murah juga karena ajakan dari keluarga yang sudah terlebih dulu menjadi migran. Karena pendapatan diluar negeri lebih banyak dibandingkan dengan daerah asal. Berikut ini data tahun kepergian migran.

Tabel 6. Tahun Kepergian Migran

\begin{tabular}{ccc}
\hline Tahun & Jumlah & $\%$ \\
Kepergian & & \\
\hline$<2000$ & 1 & 2,9 \\
$2000-2010$ & 22 & 64,8 \\
$>2010$ & 11 & 32,4 \\
\hline Jumlah & 34 & 100 \\
\hline
\end{tabular}

Sumber: Data Primer

Data Tabel 6, menunjukan bahwa pada interval tahun 2000 - 2010 lebih yang paling banyak nmenjadi tahun kepergian para migran yaitu sebesar 22 orang atau 64,8\%. Begitu juga bagi migran yang pergi pada interval $>2010$ yaitu sebanyak 11 orang atau $32,4 \%$ dan bagi migran yang pergi pada tahun $<2000$ hanya sebanyak 1 orang atau $67 \%$.

\section{Tempat/Negara Pekerjaan Migran}

Tabel 7 menjelaskan negara tempat pekerjaan migran. Penjelasan cera rinci dapat dilihat pada Tabel 7 .

Tabel 7. Sebagian Besar Migran Selama Bekerja Diluar Negeri Atau Sementara Tinggal Di Luar Negeri

\begin{tabular}{ccc}
\hline $\begin{array}{c}\text { Negara tempat } \\
\text { migran }\end{array}$ & Jumlah & $\%$ \\
\hline Amerika & 14 & 41,2 \\
Singapura & 4 & 11,8 \\
Jepang & 11 & 32,3 \\
Hongkong & 3 & 8,9 \\
Korea & 1 & 2,9 \\
Spanyol & 1 & 2,9 \\
\hline Jumlah & 34 & 100 \\
\hline
\end{tabular}

Sumber: Data Primer

Sebagian besar migran selama bekerja sementara tinggal di Amerika yang paling banyak yaitu sebanyak 14 orang atau $41,2 \%$, bekerja di Singapura yaitu sebanyak 4 orang atau $11,8 \%$, bekerja di jepang sebanyak 11 orang atau 32,3\%, Yang bekerja di Hongkong sebanyak 3 orang atau $8,9 \%$, Selanjutnya Korea dan Spanyol masing-masing hanya 1 orang atau $2,9 \%$. 


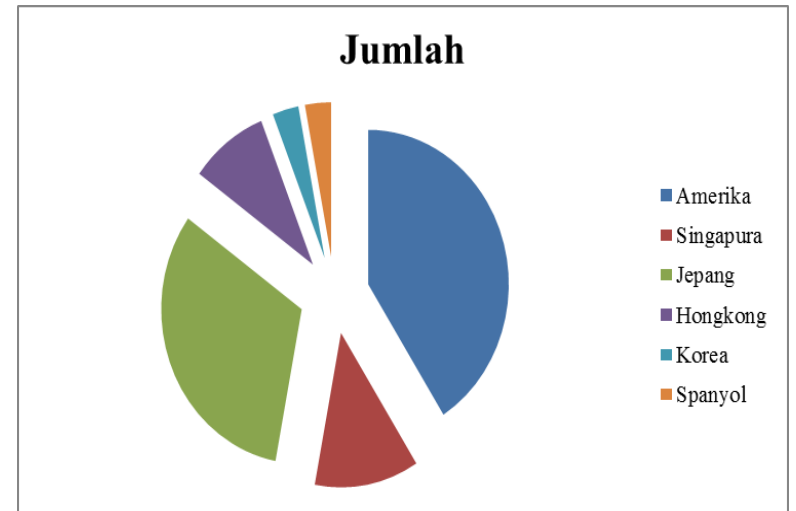

Gambar 3. Persentase Tempat/Tujuan Kepergian Migran Berdasarkan Jumlah Migran

\section{Alasan Melakukan Migrasi}

Dilihat dari kenyataan, keadaan ekonomi Indonesia yang relatif lebih rendah dibandingkan dengan daerah lainnya kelihatan menjadi alasan utama yang menyebabkan migran meninggalkan kampung halamannya untuk masa yang tidak ditentukan. Hal ini dapat kita perhatikan melalui hasil penelitian pada Tabel 8 .

Tabel 8. Alasan Migran Meninggalkan Kampung Halaman

\begin{tabular}{lcc}
\hline \multicolumn{1}{c}{ Alasan } & Jumlah & $\%$ \\
\hline Memperbaiki & 27 & 79,4 \\
$\begin{array}{l}\text { Perekonomian Keluarga } \\
\text { Tugas }\end{array}$ & 1 & 2,9 \\
Mencari Pengalaman & 6 & 17,7 \\
\hline \multicolumn{1}{c}{ Jumlah } & 34 & 100 \\
\hline
\end{tabular}

Sumber: Data Primer

Hasil penelitian menunjukkan alasan migran yang paling utama meninggalkan daerah asal adalah karena faktor ekonomi, untuk memperbaiki perekonomian keluarga, serta keinginan untuk mendapatkan penghasilan yang lebih tinggi. Sebagian kecil saja migran meniggalkan daerah asal dengan alasan karena ingin mencari pengalaman. Ada juga migran meninggalkan daerah asal karena tugas kantor.

Didukung oleh alasan migran meninggalkan daerah asal karena migran kurang atau tidak memperoleh peluang ekonomi didaerah asalnya. Apalagi kalau sakiranya pendidikan migran rendah, akan lebih sulit bagi migran untuk bersaing di pasaran tenaga kerja.

\section{Keadaan/Kondisi Pendapatan Sebelum dan Sesudah menjadi Migran}

Keadaan pendapatan sebelum dan sesudah menjadi migrasi dapat dilihat pada Tabel 9.

Tabel 9. Tingkat pendapatan sebelum Melakukan Migrasi (Rp/bulan)

\begin{tabular}{ccc}
\hline Penghasilan (Rp/bukan) & Jumlah & $\%$ \\
\hline$<1.000 .000$ & 14 & 41,1 \\
$1.000 .000-5.000 .000$ & 20 & 58,9 \\
$>5.000 .000$ & - & - \\
\hline Jumlah & 34 & 100 \\
\hline
\end{tabular}

Sumber: Data Primer

Tabel 9. Menunjukkan bahwa tingkat pendapatan migran $<1.000 .000$ yaitu sebanyak 5 orang atau $14,7 \%$. dan tingkat pendapatan Migran sekitar 1.000.0005.000 .000 yaitu sebanyak 20 orang atau 58,9\%. Sedangkan dari migran yang belum mempunyai pekerjaan sebesar 26,4\% atau 9 orang. dengan keadaan ini sangat memprihatinkan karena dengan penghasilan kecil migran dapat membiayai keluarga migran. Penghasilan tersebut pada umumnya tidak cukup untuk memenuhi keperluan migrant sehari-hari ketika masi berada di daerah asal.

Tabel 10. Tingkat Pendapatan Sesudah Melakukan Migrasi (Rp/bulan)

\begin{tabular}{ccc}
\hline Penghasil $(\mathrm{Rp} /$ bulan$)$ & Jumlah & $\%$ \\
\hline$<1.000 .000$ & - & - \\
$1.000 .000-5.000 .000$ & 5 & 11,8 \\
$>5.000 .000$ & 29 & 88,2 \\
\hline Jumlah & 34 & 100 \\
\hline
\end{tabular}

Sumber: Data Primer

Tabel 10. Menunjukkan bahwa tingkat pendapatan migran adalah sekitar $>5.000 .000$ yaitu sebanyak 30 orang atau $88,2 \%$. sedangkan dari migrant yang berpendapatan $3.000 .000>5.000 .000$ yaitu sebanyak 4 orang atau $11,8 \%$. Setelah melakukan migrasi para migran sudah dapat mencukupi atau memenuhi kebutuhan keluarganya bahkan dari tidak mempunyai pemilikan apa-apa menjadi mempunyai pemilikan sepertih rumah, tanah, sawah dan tabungan, dan sebagainya. 
Tabel 11. Penghasilan ditinjau dari Pendidikan dan Jenis Kelamin

\begin{tabular}{ccccccccccc}
\hline Penghasilan & \multicolumn{10}{c}{ Pendidikan } \\
\cline { 2 - 10 } (Rp/Bulan) & SMP & \multicolumn{1}{c}{ SMA } & \multicolumn{1}{c}{ SMK } & \multicolumn{2}{c}{ D3 } & \multicolumn{2}{c}{ S1 } \\
\cline { 2 - 10 } & L & P & L & P & L & P & L & P & L & P \\
\hline$<1.000 .000$ & & & & & & & & & & \\
$1.000 .000-5.000 .000$ & 2 & & 1 & 1 & & & 1 & & & \\
$>5.000 .000$ & & & 8 & 9 & & 7 & 3 & & 2 & \\
\hline Sumber: Data Primer & & & & & & & & & &
\end{tabular}

Tabel 11. Menunjukkan tingkat pendapatan suatu migran tidak dipengaruhi dari tingkat pendidikan saat migran mulai bekerja dan pada umumnya yang melakukan migrasi adalah Perempuan.

\section{Pekerjaan Migran Sebelum Dan Sesudah Migrasi}

Alasan migran memilih bekerja di Luar Negeri yaitu karena umumnya pekerjaan migran ketika masih di daerah asal adalah sektor infolmal. Jenis pekerjaan ini seperti petani dan bergerak dibidang jasa. Ada juga sebelum melakukan migrasi belum bekerja. Adapun jenis pekerjaan migran ketika masih berada di daerah asal dapat di lihat pada Tabel 12.

Tabel 12. Pekerjaan Migran di Daerah Asal Sebelum Melakukan Migrasi

\begin{tabular}{lcc}
\hline \multicolumn{1}{c}{ Jenis Pekerjaan } & Jumlah & $\%$ \\
\hline Petani & 12 & 35,2 \\
Peternak & 4 & 11,8 \\
Pendeta & 1 & 2,9 \\
Pegawai negeri & 1 & 2,9 \\
Pegawai swasta & 5 & 14,8 \\
Karyawan toko & 2 & 5,8 \\
Tidak Punya Pekerjaan & 9 & 26,5 \\
\hline \multicolumn{1}{c}{ Jumlah } & 34 & 100 \\
\hline
\end{tabular}

Sumber: Data Primer

Tabel 12, menunjukkan bahwa sebagian besar dari migran pada awalnya bekerja sebagai petani yaitu sebesar $35,2 \%$ atau 12 orang dari kesseluruhan migran responden.

Semua orang pastilah sangat menginginkan apa yang diharapkan bisa tercapai, tidak terkecuali oleh para migran. Migran mempunyai harapan yang sangat tinggi agar setelah berada di luar negeri, migran bisa mendapatkan gaji yang tinggi sehingga tingkat kesejahteraan migran bisa menigkat bahkan bagi keluarga yang di tinggalkan dapat ikut merasakan jerih payah migran selama berada di Luar Negeri. Dan ternyata harapan dan keinginan migran untuk mendapatkan pekerjaan dan penghasilan yang cukup tinggi tercapai. Pendapatan migran meningkat jauh dibandingkan dengan sewaktu masih berada didaerah asal.

Tabel 13. Jenis Pekerjaan Migran Setelah Migrasi

\begin{tabular}{lcc}
\hline \multicolumn{1}{c}{ Jenis Pekerjaan } & Jumlah & $\%$ \\
\hline Pegawai Negeri & 1 & 2,9 \\
Pendeta & 1 & 2,9 \\
Asisten RT & 15 & 44,2 \\
Supir & 7 & 20,5 \\
Pegawai & 4 & 11,8 \\
Perusahaan & & \\
Pegawai Pabrik & 6 & 17,7 \\
\hline \multicolumn{1}{c}{ Jumlah } & 34 & 100 \\
\hline
\end{tabular}

Sumber: Data Primer

Tabel 13. Menunjukan bahwa para migran sebagian besar bekerja di Daerah tujuan sebagai Asisten RT dengan jumlah 15 orang atau $44,2 \%$, sedangkan yang paling sedikit bekerja sebagai Pegawai Negeri Dan Pendeta masing-masing hanya 1 orang atau $2,9 \%$.

\section{Dana Remitansi}

\section{Alokasi Remitansi}

Remitansi yang paling penting dan sangat dibutuhkan serta mampu membawa keluarga Migran pada kesejahteraan adalah uang. Bagi migran yang mengirim uang setiap bulan itu dikarenakan migrant ingin member atau menyisihkan hasil jerih para migran untuk keluarga, biasanya untuk orang tua sebagai tanda bahwa migran sudah bisa membantu atau ikut menaikkan taraf kehidupan keluarga yang migran tinggalkan.

Tabel 14. Penggunaan Remitansi Yang Di Terima

\begin{tabular}{lc}
\hline \multicolumn{1}{c}{ Penggunaan Remitansi } & Alokasi (\%) \\
\hline Kebutuhan/pengeluaran sehari-hari & 18,2 \\
Renovasi Rumah & 35,1 \\
Beli Tanah & 21,3 \\
Tabungan & 10,0 \\
Biaya Sekolah & 9,2 \\
Lain-lain & 6,2 \\
\hline \multicolumn{1}{c}{ Jumlah } & 100 \\
\hline
\end{tabular}

Sumber: Data Primer

Tabel 14, menunjukkan bahwa sebagian besar penggunaan Remitansi untuk Renovasi rumah yaitu dengan persentase $35,1 \%$. 
Tidak hanya pengiriman remitansi setiap bulan, ada juga Remitansi yang di terima keluarga migran pada saat migran pulang ke daerah Asal. Jumlah Remitansi berkisar Rp.50.000.000 s/d Rp.150.000.000 setiap tahun. Selanjutnya pada tabel 15 disajikan data Jumlah Remitansi/tahun.

Tabel 15. Jumlah Remitansi Yang Diterima Keluarga setiap Migran Pulang Ke Daerah Asal

\begin{tabular}{ccc}
\hline Kelas Remitansi & Jumlah & $\%$ \\
\hline$<50.000 .000$ & 2 & 5,9 \\
$50.000 .000-75.000 .000$ & 20 & 58,9 \\
$>75.000 .000$ & 12 & 35,2 \\
\hline Jumlah & 34 & 100 \\
\hline
\end{tabular}

Sumber: Data Primer

Tabel 15. Menjelaskan bahwa jumlah uang yang dikirim keluarga terbesar barada padah jumlah Rp.50.000.000 - Rp.75.000.000 yaitu sebesar $58,9 \%$ dan paling sedikit berada pada jumlah kurang dar Rp.50.000.000 yaitu $5,9 \%$.

Tabel 16. Jumlah Pendapatan Ditinjau Dari Tingkat Pendidikan

\begin{tabular}{ccccc}
\hline Jumlah & \multicolumn{3}{c}{ Pendidikan } & \\
\cline { 2 - 4 } Pendapatan & SMP & SMA & D3/S1 & Jumlah \\
\hline$<50.000 .000$ & 1 & & & 1 \\
$50.000 .000-75.000 .000$ & 1 & 19 & & 20 \\
$>75.000 .000$ & & 11 & 2 & 13 \\
\hline Jumlah & 2 & 30 & 2 & 34 \\
\hline Sumber: Data Primer & & & &
\end{tabular}

Tabel 16. Menunjukkan bahwa jumlah pendapatan tidak bergantung pada tingkat pendidikan Migran.

Tabel 17. Jumlah pendapatan Ditinjau Dari Lama Merantau

\begin{tabular}{cccc}
\hline Jumlah & \multicolumn{3}{c}{ Lama Merantau } \\
\cline { 2 - 4 } Pendapatan & $<5$ & $5-10$ & $>10$ \\
\hline$<50.000 .000$ & 2 & & \\
$50.000 .000-75.000 .000$ & 3 & 10 & 5 \\
$>75.000 .000$ & 2 & 10 & 2 \\
\hline Jumlah & 7 & 20 & 7 \\
\hline Sumber: Data Primer & & &
\end{tabular}

Tabel 17 menunjukkan bahwa lama merantau ada pengaruh dalam jumlah Pendapatan yang akan diterima Migran.

\section{Informasi Atau Ide-ide}

Remitansi juga dapat berupa Informasi atau ide-ide ke daerah asal melalui telepon. Informasi yang sering diterima dari para migran untuk keluarga dan masyarakat di daerah asal.
Informasi atau ide-ide yang dikirimkan biasanya berupa hal-hal yang menyangkut tentang etos kerja atau kesempatan ataupun peluang kerja yang biasanya disampaikan Migran melalui telepon kepada keluarga kemudian keluarga menyampaikan kepada orang sekitar keluarga yang berminat atau tertarik/suka.

Alokasi remitansi kebanyakan migran merenovasi rumah migran atau membeli tanah/rumah, dan uang untuk merenovasi atau membeli rumah biasanya sebesar 40-50\% dari Pendapatan yang diterima. Namun ada juga dari migran yang membeli rumah sebagai ivestasi, ada juga dari Migran memanfaatkan Remitansi untuk biaya sekolah anak. Sawah juga menjadi salah satu pilihan untuk menginvestasikan uang Migran, sebagian kecil dari migran membeli mobil sebagai investasi dan yang sisanya ditabung. Dengan adanya migrasi selain mempengaruhi peningkatan pendapatan keluarga migran dan mempengaruhi kesejahteraan keluarga migran tetapi dengan adanya migrasi mempengaruhi perkembangan harga tanah di Kecamatan Langowan Utara tepatnya Desa Walantakan, Desa Karumenga, Desa Toraget, Desa Taraitak, Desa Taraitak1.

\section{KESIMPULAN DAN SARAN}

\section{Kesimpulan}

Alokasi Remitansi lebih meningkatkan taraf hidup dan Pendapatan serta kesejahteran kehidupan keluarga para migran. Melalui alokasi remitansi khususnya keluarga Migran yang menerima Remitansi, seperti membeli tanah, sawah, merenovasi rumah dan membeli mobil sebagai investasi. Sebagian besar keluarga migran mengalokasikan dana remitansi untuk merenovasi rumah dengan persentase $35,1 \%$.

\section{Saran}

Hendaknya memanfaatkan Remitansi agar lebih diatur sedemikian rupa agar supaya alokasi Remitansi dari keluarga Migran di pakai untuk pembangunan desa yang lebih baik, dan membangun lapangan pekerjaan. 


\section{DAFTAR PUSTAKA}

Ratha et al. 2011. Pengaruh Pendapatan,

Pendidikan dan Remitansi Terhadap

Pengeluaran Konsumsi Pekerja

Migran Nonpermanen Di Kabupaten

Badung (Studi Kasus Pada Dua

Kecamatan Di Kabupaten Badung).

Dalam Jurnal Ekonomi Pembangunan

Universitas Udayana, 4(2). 